Portland State University

PDXScholar

\title{
Teaching the Middle East in Portland Public High Schools
}

Nicholas C. Jenkins

Portland State University

Follow this and additional works at: https://pdxscholar.library.pdx.edu/honorstheses Let us know how access to this document benefits you.

\section{Recommended Citation}

Jenkins, Nicholas C., "Teaching the Middle East in Portland Public High Schools" (2016). University Honors Theses. Paper 246.

https://doi.org/10.15760/honors.268

This Thesis is brought to you for free and open access. It has been accepted for inclusion in University Honors Theses by an authorized administrator of PDXScholar. Please contact us if we can make this document more accessible: pdxscholar@pdx.edu. 
Teaching the Middle East in Portland Public High Schools

by

Nicholas C. Jenkins

An undergraduate honors thesis submitted in partial fulfillment of the requirements for the degree of

Bachelor of Arts

in

University Honors

and

History, Philosophy

Thesis Advisors

Dr. Audrey Lingley, EdD

Howard Yank, M.A.

Portland State University

2016 


\section{Table of Contents}

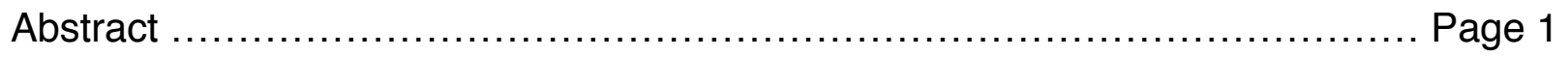

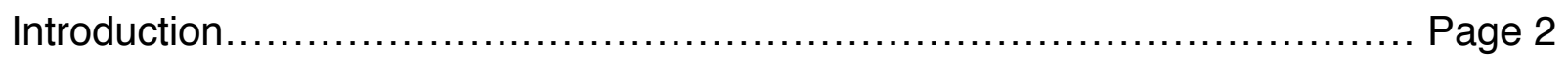

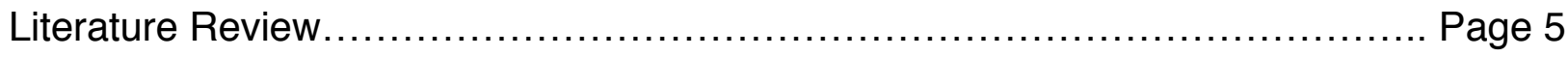

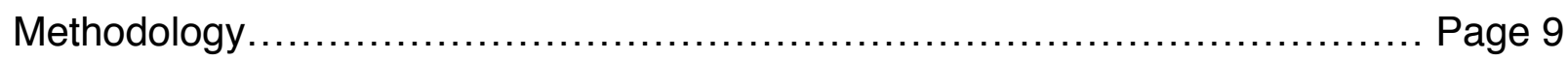

Description of Data Results

- Interviews

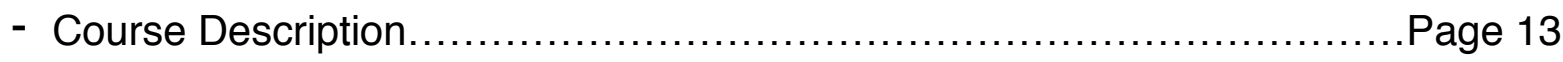

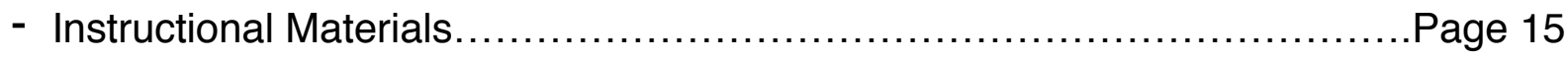

- Teachers' Assessment of the Middle East in their Classrooms................Page 18

- Textbooks

- Modern World History: Patters of Interaction................................ Page 19

- History Alive! Pursuing American Ideals................................... Page 22

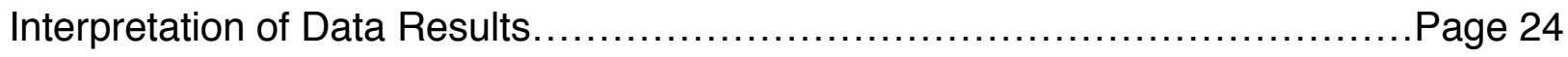

Conclusion and Possible Next Steps.............................................. 31

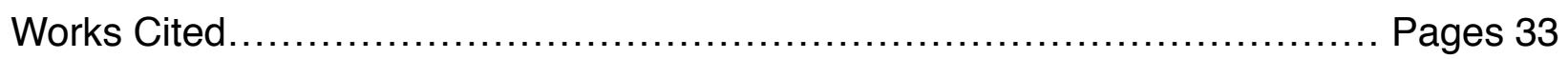

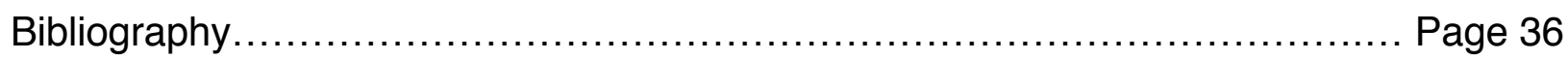

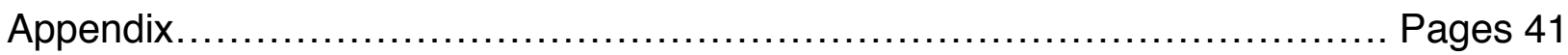




\begin{abstract}
This paper examines the ways in which the Middle East is taught to high school students in Portland Public School. Specifically, it focuses on the required history courses, Modern World History and United States History for Freshman and Juniors, respectively. Beginning with a definition of the Middle East, this paper starts by placing itself and the author within a discourse community of educators, historians, and writers who discuss the issues with incorporating multiple points of view into their curriculum. After a discussion of the methods by which the data was collected, this paper concludes by offering a description of that data, as well as an interpretation of the results. Data collection in this case was done by way of interview with four teachers from four different schools in Portland Public, as well as in-depth content analysis of the two textbooks that were adopted by the Portland Public School District in 2008. Through this research, this paper concludes by offering a brief glimpse into the difficulties facing these teachers in incorporating the complex issues surrounding the Middle East in required high school history classes.
\end{abstract}




\section{Introduction and Background}

You would be hard-pressed to find a person alive today who does not have a story about where they were during the attacks on the World Trade Center on September 11, 2001. My own story involves me and my mom holding each other close with our eyes fixed on a small black and white TV as our local newscasters informed us of what had happened all the way across the country. It would be years of public school education and media consumption before I would arrive where I am today with a basic understanding of the history of the region where these attacks originated. The problem however, as historians like James Loewen in his book Lies My Teacher Taught Me: Everything Your American History Textbooks Got Wrong ${ }^{1}$ addressed, is that it very likely that what I learned about the origins of these attacks, and about the larger context of the Middle East, was inaccurate, distorted, or patently false. Now that I am an adult, the responsibility for to seek out the accurate information falls squarely on my shoulders. But for students in Portland Public Schools (abbreviated PPS) today, it is perhaps more important than ever that they have a proper understanding of the history of the Middle East as the world continues to move towards a more globalized future.

In doing this project I sought to examine how teachers and the district come together to provide students with content related to the Middle East through teaching methods, lesson plans, instructional materials, and curriculum. I intended to understand what role the events of September 11, 2001 played in shaping and changing the quantity and/or quality of content that is taught to students about the Middle East. This research was framed around the idea of how required history courses in Portland Public

1 James Loewen, Lies My Teacher Told Me: Everything Your American History Textbook Got Wrong (New York NY: Touchstone, 1995). 
Schools changed the way the Middle East is taught since September 11, 2001, in terms of teaching methods, curriculum, teaching materials, and lesson plans. Additional points of inquiry sought to explore if the content about the Middle East had changed, in what ways had it changed, and what the reasons for any changes may have been.

To conduct this analysis, I first needed to establish a definition for what the "Middle East" is. The Middle East is a term that has historically evolved out of colonial policy of the 19th and 20th centuries, and in a 21st century context the term is not appropriate without a specific discussion of which countries qualify. Despite this, the phrase still persists in the common vernacular. As such, for the purposes of this study and for the sake of brevity, I will use the definition "Middle East" to refer to the following countries:

- Egypt

- Saudi Arabia

- Yemen

- Oman

- United Arab

Emirates
- Qatar

- Bahrain

- Kuwait

- Iraq

- Iran

- Jordan
- Israel/Palestine

- Lebanon

- Cyprus

- Turkey

- Syria

This is the definition that is used by Brown University's Choices Program, which publishes text and electronic versions of textbooks, lesson plans, and interactive materials. Written by members of the Watson Institute for International Studies, this list of countries comes from the Choices Program textbook The Middle East in Transition: Questions for U.S. Policy. Though I looked at several different sources from places such 
as the $\mathrm{CIA}^{2}$, print books ${ }^{3}$, and journal articles ${ }^{4}$, this particular definition was chosen for its usefulness in the context of social studies education.

With this definition in mind, over the course of this project I relied on a variety of sources of data in order to examine the influence and/or shift in curriculum around the Middle East under this definition. This material came from interviews with teachers who teach the required history courses in PPS (Modern World History and U.S. History), as well as quantitative and qualitative analysis of district adopted textbooks. In addition, I examined literature from primarily history scholars, which reveal ways in which this and other historical events have shaped and continue to shape the ways in which we instruct our students. By examining this change, one can better understand ways in which the Middle East was and is currently discussed in PPS high school history classrooms. Initially, I expected that following September 11, 2001 the amount of content increased, but I intended to investigate how, why, and to what degree that content had changed. In doing so, I was instead able to get a glimpse into the ways in which teachers address the task of teaching about the Middle East in their classrooms and explore the materials that they use, as well as the materials adopted by the district.

\footnotetext{
2 "The Middle East", United States Central Intelligence Agency (Washington, D.C.: Central Intelligence Agency), 1990, https://www.loc.gov/resource/g7420.ct000919/.

3 Efraim Karsh, Rethinking the Middle East (Taylor \& Francis, 2003), <http:// www.myilibrary.com?ID=4674> (Accessed April 12th, 2016)

4 Michael Petrou, "An Ancient War Is New Again: A Bitter, Violent Clash between Islam's Two Main Sects Is Dividing And, Increasingly, Defining the Middle East." Maclean's, January 13, 2014. Academic OneFile, http://go.galegroup.com/ps/i.do?id=GALE $\% 7 C A 355776515 \& v=2.1 \& u=s 1185784 \& i t=r \& p=A O N E \& s w=w \& a s i d=0 b 9 a 04 c 46 f 5 f 06374043157$ 1719120ed (Accessed May 1st)
} 


\section{Literature Review}

Before I was able to begin collecting data to investigate any possible change, I first reviewed literature relevant to this topic and discussion at large. This section highlights some of the sources I examined, and discusses them as part of a broad discourse community in which I place myself. This discussion follows the various authors' research questions, their methods, and their interests in order to see how their work informs mine, and what similarities my work shares with theirs. My discourse community is made up of educators, historians, curriculum theorists, and sociologists.

Many of the sources that I have looked at have come from current or former educators in the field of history. This is partially due to the fact that, more often than not, many history researchers do teach or have taught in the past. More importantly, however, is the fact that these are people that are impacted by the concept that I am trying to articulate and further explore. Each of the authors discussed has been an educator in either K-12 school districts, universities, or both. Their individual backgrounds inform the research they have done and the research questions they are exploring. The article discussed by Stephen Andrews ${ }^{5}$ and Barry Franklin ${ }^{6}$ (both university educators), deal with the nature of history curriculum in the university systems in the United States. On the other hand, Elavie Ndura's7 background as a secondary educator with a specialty on multilingual and multicultural education informs her

\footnotetext{
5 Stephen D. Andrews, "Structuring the Past: Thinking about the History Curriculum," Journal of American History 95, no. 4 (March 2009): 1094-1101.

6 Barry M. Franklin, "Review Essay: The State of Curriculum History." History of Education 28, no. 4 (December 1999): 459-76. doi:10.1080/004676099284573.

7 Elavie Ndura, "ESL and Cultural Bias: An Analysis of Elementary Through High School Textbooks in the Western United States of America," Language, Culture and Curriculum 17, no. 2 (June 1, 2004): 143-53, doi:10.1080/07908310408666689, Accessed November 8th, 2015
} 
research on cultural biases in ESL textbooks in K-12 textbooks. These educators made use of their personal experiences to explore challenges and issues that they have faced with the curriculum in their own classrooms, whether in a broad sense like Andrews and Franklin, or more focused around a specific set of biases like Ndura. They make use of a variety of sources to support their theses by way of case study examples or statistical data. This includes first hand accounts of the teaching methods used in their classrooms and the adoption of certain textbooks (in the case of the Ndura article). Meanwhile, authors like Holly Arida ${ }^{8}$ and Khodadad Kaviani ${ }^{9}$ taught classes which sought to teach students about the Middle East and the events of September 11, 2001 in new and different ways.

The next groups in my discourse community are historians themselves. The authors I read look at how history education specifically has changed over time. In her article "The Pragmatic Roots of Public History Education in the United States", Rebecca Concord ${ }^{10}$ looks at how multiple different philosophies, pedagogies, and social factors allowed for the division and specialization of history courses at universities in the United States. In calling upon primary and secondary sources, her research demonstrates what seems obvious but nevertheless is important to my work: history education changes, and more often than not, the reasons why and the ways how are not simple or one dimensional.

\footnotetext{
8 Holly Arida, "Teaching The Middle East: The Perspectives Method," Teaching History: A Journal of Methods, 2006, General OneFile, accessed November 22nd, 2015.

9 Khodadad Kaviani, Media and Teaching about the Middle East, vol. 5 (International Association of Educators, 2009), http://eric.ed.gov/?id=ED504147. Accessed April 6th, 2016. 10 Rebecca Concard, "The Pragmatic Roots of Public History Education in the United States," The Public Historian 37, no. 1 (February 2015): 105-20.
} 
Other articles specifically deal with this issue as it relates to $\mathrm{K}-12$ schools. William C. Kashatus III'11, for example, discusses ways in which the multidisciplinary nature of "social studies" dilutes an accurate account of US history for students. Though his work relies strictly on his own experience and testimony, his view offers ways in which teachers can engage with their students on subjects that the curriculum or textbooks may under-describe or misrepresent. This is something that James Loewen ${ }^{12}$, a sociologist, touches on heavily in his book Lies My Teacher Told Me: Everything Your American History Textbook Got Wrong. Specifically, his last chapter about the way selected textbooks discuss the US engagement in the Middle East after September 11, 2001 informs much of the work I did in looking at this issue in Portland Public Schools. Where his work looks exclusively at textbooks, however, my work additionally focused on how the teachers themselves responded to and taught the subject. This is something that Jane Hansen ${ }^{13}$ does in her classroom case study. Here, she engages directly not only with the teacher, but the students as well, as they discuss, engage with, and explore their own feelings about issues such as race, ethnicity, and social class in US history. Her work presents one system of qualitative analysis in regards to engagement and understanding of history through students' own writing.

The last group in my discourse community is articles from scholars that do not traditionally fit directly into either of the former two categories I have discussed. The first

\footnotetext{
11 William C. III. Kashatus, "Forging a Link with 'Our' Past": The Responsibility of Teaching American History," History Teacher 24, no. 1 (November 1990): 113-19.

12 James Loewen, Lies My Teacher Told Me: Everything Your American History Textbook Got Wrong (New York NY: Touchstone, 1995).

13 Jane Hansen, "Multiple Literacies in the Content Classroom: High School Students' Connections to U.S. History," Journal of Adolescent \& Adult Literacy 52, no. 7 (April 2009): 597606.
} 
is the work of Herbert M. Kliebard ${ }^{14}$, an education historian and curriculum theorist. Aligning himself with John Dewey, a well-known education reformer and philosopher, his article explores how some of the fundamental questions that are buried in history education have gone unnoticed or have been ignored over time. He argues that those oversights have been reflected in the curriculum and teaching strategies that are pervasive in history education. Work in this field of curriculum theory and education history explores research questions which use value statements as their research questions. I explored this work with the intention to explore any connection to content related to the Middle East. Lastly is the work of authors Sewall and Emberling ${ }^{15}$, who offer a quantitative analysis of where textbook publishers receive their funding and how that impacts the educational resources of the nation as a whole. Where the other scholars I have discussed deal directly with topics in history after the teaching material has already reached the institutions, this kind of quantitative analysis offers answers to questions as to how this material gets to schools in the first place. In my own research, I looked at current textbooks which were given to students as part of the required history courses. Having an understanding as to how this information got to the students is integral in answering how and why the content has changed.

This is the discourse community I found myself in as I conducted my research. I have described and analyzed how members from the education, history, sociology, and curriculum theory groups have influenced my work, by way of methodology, data

\footnotetext{
14 Herbert M. Kliebard, "Why History of Education?," Journal of Educational Research 88, no. 4 (April 3, 1995): 194.

15 Gilbert T. Sewall and Stapley W. Emberling, "A New Generation of History Textbooks," Society 36, no. 1 (December 11, 1998): 78-82.
} 
collection and analysis, and establishment of research questions. Within this discourse community, I was able to put these tools towards conducting my own research.

\section{Methodology}

My research was conducted in three parts: a literature review to establish my discourse community (found in the section above), interviews with Portland Public high school history teachers, and analysis of district adopted textbooks. Part of this review sought to establish an understanding of current pedagogical methods, districtsanctioned curriculum, the timeline of events centered around September 11, 2001, as well as a functional definition of the "Middle East". The literature came from sources accessible though the Portland State University Library, the Summit Library System, and journal databases provided by each.

Following the literature review, I interviewed teachers currently working in Portland Public high schools. After sending out emails detailing my project, I conducted interviews with four teachers from four different schools, one of whom had been teaching before September 11. At the time of this writing, one teacher has just started their career at three years (Teacher A), two have been teaching for thirteen years (Teacher B and Teacher C), and the last has nearly eighteen years under their belt (Teacher D). Each teacher has spent most of their careers at Portland Public Schools, and each has taught at at least two schools. All four of the teachers that I interviewed either have taught or are currently teaching some version of Modern World History or US History. ${ }^{16}$ Each teacher that I spoke to has taught both of the required history

16 Although at some schools these classes may be called something else, they are functionally the same. 
courses as dictated by PPS (Modern World History at the Freshman level, and US History at the Junior level). Each of these teachers have also had experience teaching either an Advanced Placement (AP) or International Baccalaureate (IB) class, such as AP US, IB Psychology, AP Philosophy, IB History of the Americas, and IB 20th Century World History. With that being said, the course offerings at the schools do not necessarily look the same. One school in the PPS district, for example, just recently changed their history requirements from US History being a Freshman level class, to renaming it US Cultural Studies and requiring it for Juniors instead. Though in name the classes may be different, the teacher I spoke to had the same expectation of work load for the Freshman as they did for the Juniors, implying that when the coursework was designed for Freshman there were already high expectations. When students' parents came for Back to School Night and saw the work the Freshman were doing, they often remarked that it resembled work they themselves did in college. These comments continued even after it was made a class for Juniors instead. Similarly, other teachers at other schools incorporate different assignments, activities, and coursework compared to their counterparts at another school would use. Meanwhile, another PPS school is offering a History of the Middle East course for the first time in the 2015/2016 school year. These interviews were recorded on February 17th, 18th, 24th, and March 1st and varied between thirty and forty five minutes in length. The purpose of these interviews was meant to be freeform and conversational, while specifically asking the teachers to address the following questions: 
- How long have you been teaching? How many of those years were spent in Portland Public? Which schools have you taught at?

-What courses do you teach/have you taught?

- How much of your course was spent teaching the Middle East before September 11, 2001 ? (Measured by units, assignments, lectures, and readings) ${ }^{17}$

- How much of your courses is spent teaching the Middle East? (Measured by units, assignments, lectures, and readings)

-What sort of instructional material do you use in your classes to discuss the Middle East?

- Does the material you taught or currently teach reflect a need for greater understanding of this region following September 11, 2001?

- Do you feel the amount of material dedicated to the topic of the Middle East before and after September 11 was too much, not enough, or satisfactory? Why?

- As time has passed, have you seen the required material in your classes change the way in which they discuss the Middle East?

Following the interviews, I proceeded with a content analysis of the district adopted high school history textbooks. I was able to do this by spending several hours spread from March to the end of April at the Portland Public Schools Instructional Resource Center. These textbooks were Modern World History: Patterns of Interaction ${ }^{18}$

17 This question was asked to the one teacher who had been teaching before September 11, 2001.

181. MCDOUGAL LITTEL, World History: Patterns of Interaction: Student Edition 2007, Student edition (Evanston, III.: MCDOUGAL LITTEL, 2007). 
and History Alive! Pursuing American Ideals. ${ }^{19} \mathrm{I}$ began first by looking in the table of contents of both books, looking for any chapters that discussed the Middle East directly, and then turning to the index and searching for the countries by name. This content was analyzed both qualitatively, in regards to the context in which the country was discussed, as well as quantitatively, in terms of page count and the number of paragraphs in which the country is mentioned in the text.

Additionally, the original scope of this project included a broader discussion of the teachers' experience of teaching about the Middle East in the classroom since before September 11, 2001, as well as a larger analysis of the textbooks that were used prior to the current textbooks named above. However, due to limited availability or lack of interest, no other teachers were available to be interviewed. The one teacher who had been teaching before September 11, 2001 was able to provide some insight into this comparison, though they no longer had access to their instructional materials nor their lesson plans or booklists from that time. Additionally, as I was told by an employee of the Instructional Resource Center, there were no district adopted textbooks before 2007. Though individual teachers could order books for use in their classrooms through the district, there was no record available which detailed which teachers used which books at which schools.

\section{Description of Data Results - Interviews}

As stated in my methodology section, I interviewed four high school history teachers working for Portland Public Schools. Their names have been removed, as well

19 Diane Hart, Bert Bower, and Teachers' Curriculum Institute, History Alive!: Pursuing American Ideals (Palo Alto, CA: Teachers' Curriculum Institute, 2008). 
as any language that may indicate gender, current school of employment, past schools of employment, or any other identifying criteria. Additionally, the information in this section is organized by the topics that we discussed, rather than by teacher, by subject, or by teaching assignment. This was done so as to put the different view points from each teacher along side their colleagues for the sake of direct comparison, while at the same time organizing them under subsections that identify the point of discussion.

Furthermore, it allows for the responses of each teacher to be shown more clearly than a division by other means would.

\section{Course Description}

This section deals specifically with how much content the teachers spent teaching about the Middle East in Modern World History or US History. Of all the teachers I interviewed, only Teacher D was teaching before and during September 11, 2001. On the day of, he said the students in his Freshman class were just as confused as the rest of the world, wondering what exactly had happened and who it was that orchestrated and carried out these attacks. Despite this, Teacher D said the amount of time spent on the topic of the Middle East was "...very, very little. Really, it was a negligible amount after $9 / 11$ believe it or not". ${ }^{20}$ Teacher $D$ emphasized that this was not due to a lack of interest in the topic, nor a desire to cover it, but rather was due to difficult pedagogical decisions that every teacher faces. "So much of our curricula is US History or World History, at least in PPS". ${ }^{21}$ As such, this teacher felt that making the

20 Teacher D, interview by Nicholas Jenkins, February 17th, 2016.

21 idem 
decision of what to focus on and what content to cut to cover the history and politics of, say, America's involvement in the Middle East poses a great challenge. Furthermore, Teacher $\mathrm{D}$ prefers to be more of a generalist in courses like these. The goal of a class like this is, in this teacher's opinion, not to get focused on one particular region but to give students a broader understanding of the history as a whole as well as highlight the greater narrative that emerges in examining history on a larger scale.

Similar sentiments such as those from Teacher $D$ were echoed in interviews with other teachers, in regards to how much time was spent on the Middle East in their classrooms, despite not having taught in 2001 nor the years immediately following. Teacher A said they spent about a week and a half on the history of Islam in their Modern World History class. "This included geographical components, historical components, and religious history, but overall it is not enough". ${ }^{22}$ Teacher B said that the amount of time spent teaching the Middle East was very limited, in most cases to just a week or two. In the case of Modern World History in particular, the Middle East only comes up in a contemporary sense, with a brief discussion of the events of September 11, 2001, the Arab-Israeli Conflict, and Iran in the very recent past. Teacher C, meanwhile, identified a different approach in deciding how much time to devote to one topic. "Modern World History is organized around what regions and issues in the world seem to be the most important for this cadre of students to understand so, when they become voting citizens, they are informed". ${ }^{23}$ In Teacher C's first few years of teaching, for example, the ripple effect of the collapse of the Soviet Union and communism was

22 Teacher A, Interviewed by Nicholas Jenkins, February 22nd, 2016

23 Teacher C, interviewed by Nicholas Jenkins February 18th, 2016 
still being felt, and as such that subject had more of a focus. In the immediate years following September 11, 2001, Teacher C “hadn't incorporated what it meant to [them], let alone what it meant to the world". ${ }^{24}$ Given that, Teacher C spent a great deal of time struggling with how much and to what degree to incorporate not just the events of September 11, 2001 into the curriculum, but the history behind the issues, so as not to leave students with a simplistic narrative that did not incorporate a greater discussion of the history and interactions between the two regions that led to the events of that day and beyond. As of now, Teacher C spends six to eight weeks of their Modern World History class focused on understanding Islam and the West's interaction with Islam.

\section{Instructional Materials}

Of the teachers that I spoke to, none of them used much of the district adopted curriculum in their classes. At most, each teacher uses a chapter or a lesson in order to provide students with a tertiary source that gave the students a broad perspective that did not articulate one topic more specifically over another. Other teachers, such as Teacher $\mathrm{C}$, use the textbook in order to teach students not just how to use it, which Teacher C stressed would be a skill they needed to learn at some point, but also how to offer a critique of the textbook when placed alongside other primary and secondary sources, with the intention of identifying their own biases as well as bias recognition in general. That being said, all of the teachers said that they relied on some sort of textbook in their first few years of teaching. Though now each teacher has crafted their own curriculum to use in their classrooms, they each identified the value of a dedicated,

\footnotetext{
24 idem
} 
if somewhat broad, text on the topic for new teachers. This trend was also reported to have occurred when the teachers switched schools or were given a new teaching assignment, perhaps on a subject they were not as familiar with.

Appendix 1 is a list of several different source that the interviewed teachers currently employ in their classrooms when discussing the Middle East. I felt it was necessary to familiarize myself with each of the sources found in Appendix 1. Ranging from classroom activities, to films, manuscripts, and even graphic novels in the case of Persepolis by Marjane Satrapi ${ }^{25}$, the value of these texts is not in their complete explanation of the "Middle East" by themselves. Rather, the strength is that, when taken as a whole, several different sources allow, according to the interviewed teachers, for what they believe to be a more comprehensive understanding of different perspectives related to various issues. These perspectives come in the form of both history scholars who have thoroughly researched these topics, as well as primary and secondary sources from the voices of people living in this region who deal with these issues directly. Films, meanwhile, allow these same voices to project images and video related to these issues directly to the students.

It is by incorporating and relying on these materials that teachers are able to approach topics as complex as the Middle East in a way that makes the information applicable and accessible to students ranging from fourteen to eighteen years of age. Teacher A shifted this sort of curriculum in response to the students that they were teaching directly. Because Teacher A's school has a larger non-white student population than the schools of Teachers $\mathrm{B}, \mathrm{C}$, or D, both the students being taught and the teacher

25 Marjane Satrapi, Persepolis: The Story of a Childhood, First Edition (Pantheon, 2004). 
giving them instruction felt that hearing the experiences of people from inside the students' own cultures was of the utmost importance to facilitate comprehensive understanding and engagement with the topics. Additionally, Teacher A highlighted that even students who were non-Muslim wanted to be able to discuss the Middle East in a way that was not enflamed by the traditional rhetoric they may get from family members or the news.

Teacher B proposed that the need for greater understanding was constantly shifting for their class, their students, and their curriculum. In this sense, while perhaps in the years directly following 2001 it was enough to teach the events of September 11 and briefly discuss the history of the people responsible, at this pointing time that is not sufficient. Now this includes further instruction of America's involvement in Iran, Afghanistan, and the international responses to Syria and groups like ISIS.

Teacher C, as previously discussed, struggled with how much to discuss this topic in their classes. For the first few years following September 11, 2001, the topic was mostly limited to discussion between students before the bell rang. Now, the curriculum addresses what it means to be Muslim and what a Muslim country actually is (here defined as a country in which fifty percent of the population identify as such) and why it cannot be limited to just the Middle East.

Teacher D, who was involved in the creation and teaching of the History of the Middle East course at their school, wholeheartedly believed that a greater understanding was required. Though Teacher $D$ may reflect a more general teaching style in classes like Modern World History and US History, the incorporation of material that is used in the History of the Middle East elective into the required history class 
curriculum, as well as the sheer number of students that registered for both sections of the History of the Middle East reflected a greater desire from the student population to understand this region more clearly.

\section{Teachers' Personal Assessment of the Middle East in their Classrooms}

No teacher felt that the amount of time that they were able to devote the topic was sufficient for their Modern World History or their US History students to understand the full picture. Reasons for this included general lack of comprehensive knowledge in the subject (personally or departmentally), difficult pedagogical decisions regarding what to cover, and the lack of time since the events they wanted to teach occurred in order to develop a satisfactory curriculum that allowed for a thorough discussion of the topic. For example, Teacher B took several years to carefully develop curriculum related to the Middle East following the events of September 11, 2001. This was done so as to introduce students to the subject of the Middle East in a way that was less informed by the socio-political climate than if Teacher B were to try to discuss the issue in their classroom when they first started teaching in 2003. Of the teachers interviewed, each said that even if they were not presently teaching US History or Modern World History, were they to teach either subject again, more focus would be given to the role of the Middle East in World History as well as the role of the United States' creation of a picture of the Middle East as the antithesis of American values and ideals.

As such, in the classroom the teachers focused on the materials that hey chose to use, rather than any sort of textbook that the district had adopted to be used. That being said, the teachers did in fact specify that the different parts of their material talked 
about the Middle East in different ways. This was mostly a result of incorporating new materials into their lessons as well as revising some of the lessons they had already planned. Additionally, as new and better material was published, they were able to replaced those sources (be they primary, secondary, or tertiary) with updated materials, as long as the material allowed for a greater level of understanding, promoted better class discussion, or offered a new viewpoint which had previously not been considered.

\section{Description of Data - Textbooks}

\section{Modern World History: Patterns of Interaction}

In addition to my discussions with teachers in PPS, my other source of first-hand data collection was done by way of analysis of textbooks. Where other school districts have a strict adherence to the kinds and types of sources they are allowed to use ${ }^{26}$, teachers in Portland Public are fortunate in that not only are they allowed to make use of whatever material they see fit, but as Teacher $\mathrm{C}$ said during my interview with them, "One of the nice things about PPS is individual teachers at individual schools are given a lot of latitude to teach what they want at the high school level, provided there are the number of students to support those classes". Furthermore, PPS is also unique in the fact that there were no adopted textbooks of any kind before 2008. Put another way, before 2008, teachers were responsible with coming up with their own book lists to be ordered from the district with which to teach their classes. While certainly there were textbooks that teachers could order and use, there was no standard textbook that the district had. Although this allows for freedom in the material teachers provided to their

26 Vincent Scudella, "State Textbook Adoption", Education Commission of the States, accessed March 17th, 2016, http://www.ecs.org/clearinghouse/01/09/23/10923.pdf, 2013 
students, having a textbook proved to be extremely helpful for the interviewed teachers, especially in their first years of teaching.

This section will discuss explicitly the textbooks that have been adopted by the district. The first textbook is Modern World History: Patterns of Interaction (abbreviated MWH). Copyrighted in 2007, this book's focus is on modern world history full stop. As Jerry Bentley (one of the content consultants for this textbook and foremost world history scholars) says in his article "Why Study World History?",

"World history facilitates the recognition and construction of larger contexts in several ways: it brings focus to connections that help to explain historical developments, it encourages the framing of comparisons that help clarify the relationships between and among historical developments, and it prompts historians to recognize and analyze large-scale systems that condition historical development."27

This context provides insight into not only what this textbook is trying to accomplish, but the Freshman modern world history class as a whole: provide students with a functional understanding of the history of the world, with a significant goal to highlight and focus on the ways in which civilizations experienced cross-cultural interactions with each other. In collecting the data, I first looked through the table of contents to see if there were any chapters that directly related to the Middle East. The second chapter of the book was titled, "The Muslim World Expands". Broken into three different sections across eighteen pages, only eight of the pages and two of the sections directly related

27 Jerry Bentley, “Why Study World History?”, http://worldhistoryconnected.press.illinois.edu/5.1/ bentley.html, 2008. 
to countries that fall into this paper's definition of the Middle East. The first section, "The Ottomans Build a Vast Empire", offers a short and brief overview of the early history of the Ottoman Empire from approximately 1300 to the mid-16th century. The discussion is limited in scope to a few key figures, including Mehmed II, Timur the Lame, and Suleyman the Lawgiver. While the chapter does include some brief insight over the significance of such figures and what they accomplished as rulers, the last paragraph of this section, "The Empire Declines Slowly", offers a simplistic overview of how Suleyman set a precedent for a weak empire before concluding with "...However, the Ottoman Empire continued to influence the world into the 20th century". ${ }^{28}$ This influence is not further extrapolated here, in the rest of chapter, but is briefly mentioned in a discussion of World War I later in the book.

At this point, I turned my attention to the index of MWH and searched by country to find relevant sections of the text. Below is a table with the results:

\begin{tabular}{|l|l|l|l|}
\hline & \# of Pages & $\begin{array}{l}\text { \# of Paragraphs country } \\
\text { appears }\end{array}$ & Context \\
\hline Bahrain & N/A & N/A & N/A \\
\hline Cyprus & N/A & N/A & N/A \\
\hline Egypt & 7 & 11 & $\begin{array}{l}\text { Reforms in 19th C., } \\
\text { conflict in 20th C. }\end{array}$ \\
\hline Iran & 3 & 4 & $\begin{array}{l}\text { Cold War, Gulf War, } \\
\text { 2003 War, resources in, } \\
\text { secular rule in, leaders }\end{array}$ \\
\hline Iraq & & & Armed conflict, WMDs \\
\hline
\end{tabular}

28 LITTEL, MCDOUGAL. World History: Patterns of Interaction: Student Edition 2007. (Evanston: MCDOUGAL LITTEL, 2007), 77. 


\begin{tabular}{|l|l|l|l|}
\hline Israel & 4 & 8 & $\begin{array}{l}\text { Palestine Liberation } \\
\text { Organization, Suez } \\
\text { Crisis, Oslo Peace } \\
\text { Accords, Conflict with } \\
\text { Palestine }\end{array}$ \\
\hline Jordan & N/A & N/A & N/A \\
\hline Kuwait & 1 & 1 & Invasion by Iraq \\
\hline Lebanon & 2 & 2 & $\begin{array}{l}\text { Oslo, Conflict with } \\
\text { Israel/Palestine }\end{array}$ \\
\hline Palestine & 3 & 9 & See Israel \\
\hline Oman & N/A & N/A & N/A \\
\hline Qatar & N/A & N/A & N/A \\
\hline Saudi Arabia & N/A & N/A & N/A \\
\hline Syria & N/A & N/A & N/A \\
\hline Turkey & 3 & 3 & Turks in WWI \\
\hline United Arab Emirates & N/A & N/A & N/A \\
\hline United States & 5 & 12 & N/A \\
\hline Yemen & N/A & N/A and the Middle East" \\
\hline & & & \\
\hline
\end{tabular}

\section{History Alive! Pursuing American Ideals}

The textbook that is used for US history classes is the 2008 edition of History Alive! Pursuing American Ideals (abbreviated HA). As this text discusses history only in the context of the United States, HA spend just sixteen of its nearly eight hundred pages discussing the Middle East. Furthermore, all of the content related to the Middle East deals exclusively with American intervention in the region, with a primary focus on military engagement. While the Ottoman Empire once again does get a brief mention during the section on the end of World War I, the main Middle East content in this book does not appear until chapter 57 with the Iran-Contra Affair. In two pages, HA gives a 
short synopsis of the reasons behind the fighting and the response by the Reagan administration. From here, the next piece of Middle East content does not appear until two chapters later under the subtitle "Halting Iraqi Aggression". In just over a page HA attempts to summarize the events leading up to and the results of the Persian Gulf War and how the first Bush administration was instrumental in the American victory.

Lastly, from pages 780-793 HA discusses the War on Terror, the events of September 11, 2001, and concludes with a discussion of the founding ideals of the United States in the context of those events. ${ }^{29}$ The book spends the majority of this section discussing military engagement and the presidential response by Bush Jr., but unlike $\mathrm{MWH}, \mathrm{HA}$ presents the reader with a discussion of some of the issues that resulted from September 11 and the subsequent War on Terror. In particular, HA spends the last chapter discussing the the American people's responses to issues such as warrantless wiretaps, the conditions of prisoners in Guantanamo Bay, and even a twosided discussion of racial profiling in the private and public sector. Much like $\mathrm{MWH}, \mathrm{HA}$ lacks the discussion of Middle East influence on the United States and the world at large. Furthermore, HA makes mention of seven of sixteen Middle East countries, and the content related to those countries specifically is found on only sixteen pages. A table is not provided for this textbook not because of lack of content, but rather because the discussion of Middle East is limited to their engagement and interaction with the United States.

29Diane Hart, Bert Bower, and Teachers' Curriculum Institute, History Alive!: Pursuing American Ideals, (Palo Alto: Teachers' Curriculum Institute, 2008), 780-793 


\section{Interpretation of Data}

The teachers I interviewed are continuing to commit more and more of their instructional time to the Middle East. Though the structure of the required history classes may not allow for a clear and focused analytic discussion of the largely complex topic of Middle East history, the types of sources that they are employing in their classrooms reflect a desire to provide students with points-of-view that are not limited to the Eurocentric. Rather, teachers in Portland Public are mindfully focusing on representing the groups of people that are most intimately affected by this history, allowing those people to tell their own history, and in doing so allowing students to bridge the gap and brings themselves closer to a fuller understanding of the topic.

Furthermore, it is important to note that the material that is used by the teachers is a reflection of not just the student demographics that they tend to see year-to year but also class-to-class as well. The interviewed teachers each incorporated material that was suitable for their audiences at the time. This suggests an introspection upon their own pedagogical methods and a desire to cater to the group of students on the other side of their podiums in such a way that when they leave the class, their horizons have been expanded, rather than having been limited to one point-of-view or a single narrative.

This trend matches what I learned during my initial literature review. In her article "Teaching the Middle East: The Perspective Method" 30 , Holly Arida argues for a new curriculum that challenges students to form new perspectives on the Middle East. She

30 Holly Arida, "Teaching The Middle East: The Perspectives Method," Teaching History: A Journal of Methods, 2006, General OneFile, accessed November 22nd, 2015. 
suggests this can be done by identifying personal biases, analyzing sources for different and/or opposing perspectives to their own, and reaching an understanding of these new perspectives. Through this lens, she argues for an emphasis on teaching materials that are removed enough from bias that they can be analyzed by students who are being taught to identify and critique their own biases. Arida reiterates the challenges of teaching the Middle East to students, such as finding accurate sources and raising students awareness. She suggests that this type of methodology does just that.

Adira presents a new method to teaching students about an issue that is important for them to understand. It is clear that, at least among the four teachers I spoke to, a method similar to this which challenges students to engage their material more critically increases their engagement and understanding with the subject at hand. This was reported by all of the teachers that I spoke to both in regard to the material they continue to employ in their classrooms as well as the new material they continue to incorporate to discuss the Middle East. By allowing for the material that they use to come from various different places, as well as being presented across different formats, the interviewed teachers made it clear that they are having success in presenting students with critical information on an important part of the world, and are allowing the materials they employ to make their views heard. Furthermore, teachers like Teacher $\mathrm{C}$ are actively encouraging their students to critique and analyze their own biases as well as the biases found in material that is used in the classroom. This is not limited to the textbook, but further extends to all the materials used in order to identify who is telling which part of the story and why they are telling it. 
The work of Jane Hansen in "Multiple Literacies in the Content Classroom: High School Students' Connections to U.S. History"31, further emphasizes a methodology similar to what the interviewed teachers are doing. The argument she makes is that, rather than interacting with a single source like a textbooks, students engage with history in a more meaningful ways if they use multiple sources and connect with them in multiple ways. She organizes her piece around three connections the teacher in her study emphasized. These included the connections students had to the history, their emotional connections with said history, and how these combined when taking state tests. Through her study, she concludes that writing and interacting with their fellow students and teacher about the subject helped these students not only increase their own understanding of the past, but also helped bolster their confidence in themselves. The trends that Hansen reports here are similar to those echoed by the the interviewed teachers. By allowing for students to engage with sources and materials that more completely examine the picture, rather than just a summary overview, and then challenging the students to engage with that material by way of essay, individual or group projects, or traditional exam, the understanding they gain is greater. This discussion continues outward as students go on to higher grade levels or higher education. The four teachers I spoke to revised their curriculum and instructional materials as needed to engage their students more effectively. Additionally, the material that they employed allowed for a discussion of issues related to the Middle East, in the

31 Jane Hansen, "Multiple Literacies in the Content Classroom: High School Students' Connections to U.S. History," Journal of Adolescent \& Adult Literacy 52, no. 7 (April 2009): 597606. 
context of world history or US history, by way of voices from people experiencing those issues first hand.

In regards to the pedagogical decisions of what material to cover, this problem is not just reflected by the interviews I performed, but forward into universities as well. In "Structuring the Past: Thinking about the History Curriculum", Stephen Andrew's suggests that the development of new history curriculum and innovation in pedagogical methods in the classroom has stagnated and the result is detrimental to the students in history departments across the country. He argues that this standard history curriculum and departmental structure does not foster creative thinking and offers a disjointed history program for students. He believes that changing this would be a difficult task. In comparison to more structured programs such as mathematics, Andrew highlights how the openness of history departments can attract new students to the subject, but also eliminates a clear path towards completing a degree program. He concludes his article by suggesting that while this shift in curriculum may be difficult, history departments can give students in the major a more well-rounded and fulfilling education, while offering critical thinking and analysis tools to students taking history classes for general education requirements.

It is not difficult to apply this work to high school curriculum as well. As teachers are only given so much time to cover what can be hundreds or even thousands of years depending on the subject, the availability of substantive material can make it difficult to narrow down the scope. In doing so, it is possible that content dedicated to regions like the Middle East is limited so as to only offer a larger-scale picture of history. Allowing for specialized electives, such as the History of the Middle East course for example, can 
help to fill in these gaps. Leaving it as an elective, however, can restrict the number of students who end up receiving that instruction, whether the reason be academic probation, extracurricular actives, familial responsibilities, or lack of interest. Despite this, teachers such as Teacher D are incorporating the materials from that elective course into the required history classes as well due to their success in encapsulating topics or offering a better explanation of the topic at hand than the previous material.

It is my interpretation that the teachers that I interviewed are taking steps to introduce their students to different and more comprehensive viewpoints regarding content related to the Middle East. Though they admit that they would like to dedicate more time the subject, the amount of time that they have already dedicated does suggest that these teachers are aware of problems inherent with teaching with just a textbook and are taking the steps to avoid them. Additional and outside materials allow for greater understanding and engagement from their students, while allowing them to operate as generalists and give instruction across a wide variety of topics in their classes.

I was not able to learn the impetus behind the district's decision to adopt these textbooks in particular, nor why they chose to do so in 2007 as opposed to any time before then. Regardless, the textbooks that have been adopted by Portland Public Schools for the Freshman and Junior level required history classes are certainly functional and usable. They have not been subjected to some of the more controversial changes made to other textbooks in recent years. ${ }^{32}$ That being said, these textbooks

\footnotetext{
32 Michael Birnbaum, "Historians speak out against proposed Texts textbook changes" Washington Post, March 18th, 2010, http://www.washingtonpost.com/wp-dyn/content/article/ 2010/03/17/AR2010031700560.html
} 
are not without their problems. MWH in particular is in trouble because, as a world history textbook, it must be held to a standard which would require a focus that does not simply reflect traditional Eurocentrism. However, with just under nine hundred pages (excluding index, table of contents, definitions, etc.), Middle Eastern countries are given just twenty one pages. Across those twenty one pages, the most pages that a single country gets in discussing content related to the Middle East is Egypt with seven. After this is a two-way tie between Iraq and the United States, with five pages each. Furthermore, of the sixteen countries that are part of my definition of Middle East, nine of them are not mentioned at all, and in the cases of some countries such as Lebanon, which is mentioned on two pages, the content is limited to part of a list in discussing something else.

HA does a bit better. This book features sixteen pages of content related to the Middle East, and of that content most of it is substantive. Though it is certainly focused on the US point of view, this is consistent with the fact that it is a US history textbook. Additionally, the content that is discussed does a good job of offering two different arguments regarding issues such as race, foreign aggression, and ethnicity. Similarly, however, HA is missing nine of the sixteen countries in my definition of the Middle East, and does not pay particular attention to discussing any Middle East history prior to the late 20th century.

These history textbooks were the first to ever be adopted by the district, and even then teachers are given the freedom to forego the textbooks for other materials they deem more appropriate. Despite this freedom, it is important to look at the textbooks that have been adopted by the district because they are still used in classes. 
Though it may not be often, and though these sections may not be the ones that are covered in classes, it is important to look at the content that is sponsored by the district for use in classrooms. When these textbooks are used the information that the students are receiving from them does not accurately reflect a world view which seeks to be inclusive or representative of different world views and cultures. If the information that students receive about the Middle East is limited exclusively to what is printed in these books, their opinion of the Middle East would be one that is narrow in scope, shallow in content, and entirely focused on military engagements and acts of aggression.

The damage that textbooks such as these can do has been detailed by Elavie Ndura in "ESL and Cultural Bias: An Analysis of Elementary Through High School Textbooks in the Western United States of America". ${ }^{33}$ Ndura's argument discusses ways in which the six textbooks she analyzed demonstrated stereotyping, invisibility (omission of information) and unreality (offering a traditionalist and idealistic view instead of presenting what actually happened and why). Ndura highlights the damage that is possible when teaching from textbooks with these biases. Citing research from the Association for Supervision and Curriculum Development, she makes a particularly strong point about the invisibility of religious diversity and the damage it can have on a child in a classroom. Following this section, the author presents five different strategies ranging from simply becoming more aware of these biases, to critically examining them and presenting them alongside supplementary texts. In her conclusion, she calls for teachers to understand that textbook bias will be present in some shape and form and

\footnotetext{
33 Elavie Ndura, "ESL and Cultural Bias: An Analysis of Elementary Through High School Textbooks in the Western United States of America," Language, Culture and Curriculum 17, no. 2 (June 1, 2004): 143-53, doi:10.1080/07908310408666689, Accessed November 8th, 2015
} 
that it is important for instructors to teach their students to challenge these biases and not to perceive the textbook as infallible.

I personally used Modern World History: Patterns of Interaction as a Freshman at Grant High School in 2007. Contrary to the interviewed teachers' experiences, much of the class and homework that I did was based on the lessons, activities, and chapters in this book. In my analysis, I do not feel that either textbook reflects an accurate version of history in which the people of the Middle East are more than just failed dynasties, unstable militants, and countries to which the United States single handedly brought "democracy" in some strange post-colonial moment of crisis.

\section{Conclusion and Possible Next Steps}

This project by no means reflects the whole of Portland Public Schools. Of the nine public high schools, I was only able to interview teachers from four. None of the teachers were able to provide me with content such as past syllabi or past lecture notes, and only one of the teachers was teaching before September 11, 2001. However, where the goal of this project was to provide a comparison of the ways in which the Middle East was taught before and after September 11, 2001, this project featured interview subjects who had been teaching for as few as three years and as many as eighteen, and only closely examined the two district adopted history textbooks available in 2016. It has been successful in providing a snapshot in the ways in which different teachers at different stages of their careers approach the topic of the Middle East. Similarly, it also discusses materials and curriculum created or used by teachers at four different schools in addition to texts that have been adopted by the district. It identifies what kinds of 
materials are used and how they are incorporated into the various curriculum, and provides a glimpse into the amount of content they are able to discuss about the Middle East, and the difficulties in doing so.

Were this project to be continued, a larger pool of interview subjects would be necessary and a strong first step. While only one of the teachers that I spoke to had been teaching before September 11, 2001, of the seventy nine social studies teachers in Portland Public high schools, there are bound to be a few more. Speaking to these teachers, especially any who still had access to their curriculum from that period, would better facilitate a comparison between these two time periods. Along those same lines, it would be helpful to analyze any available instructional materials that were used at that time. These materials may come in the form of lecture notes, textbooks, handouts, films, worksheets, or any other number of sources that were not available to me at the time of this project. Furthermore, by looking at this sort of material, this research could be extended further beyond these four teachers, these four schools, and even this school district. This sort of methodology could, in theory, be used elsewhere to illustrate how, when, and in which courses the Middle East is taught in public high schools in the United States. 


\section{Works Cited}

Arida, Holly. "Teaching The Middle East: The Perspectives Method." Teaching History: A Journal of Methods, 2006. General OneFile.

Bentley, Jerry. "Why Study World History?". http://

worldhistoryconnected.press.illinois.edu/5.1/bentley.html, 2008.

Birnbaum, Michael. Michael"Historians speak out against proposed Texts textbook changes." Washington Post, March 18th, 2010. Accessed March 2nd, 2016. http://www.washingtonpost.com/wp-dyn/content/article/2010/03/17/ AR2010031700560.html

Hansen, Jane. "Multiple Literacies in the Content Classroom: High School Students' Connections to U.S. History." Journal of Adolescent \& Adult Literacy 52, no. 7 (April 2009): 597-606.

Hart, Diane, Bert Bower, and Teachers' Curriculum Institute. History Alive!: Pursuing American Ideals. Palo Alto: Teachers' Curriculum Institute, 2008.

Karsh, Efraim. Rethinking the Middle East (Taylor \& Francis, 2003). <http:// www.myilibrary.com?ID=4674>. Accessed April 12th, 2016. 
Kashatus, William C. III. "Forging a Link with 'Our’ Past": The Responsibility of Teaching American History." History Teacher 24, no. 1 (November 1990): 113-19.

Kaviani, Khodadad. Media and Teaching about the Middle East. Vol. 5. International Association of Educators, 2009. http://eric.ed.gov/?id=ED504147.

LITTEL, MCDOUGAL. World History: Patterns of Interaction: Student Edition 2007. Evanston: MCDOUGAL LITTEL, 2007.

Ndura, Elavie. "ESL and Cultural Bias: An Analysis of Elementary Through High School Textbooks in the Western United States of America." Language, Culture and Curriculum 17, no. 2 (June 1, 2004): 143-53. doi:10.1080/07908310408666689.

Petrou, Michael. "An Ancient War Is New Again: A Bitter, Violent Clash between Islam's Two Main Sects Is Dividing And, Increasingly, Defining the Middle East." Maclean's, January 13, 2014. Academic OneFile. Accessed May 3rd, 2016.

Sculdella, Vincent. "State Textbook Adoption". Education Commission of the States, 2013. http://www.ecs.org/clearinghouse/01/09/23/10923.pdf. Accessed March 17th, 2016 , 
"The Middle East." Map. Washington, DC: Central Intelligence Agency. https:// www.loc.gov/resource/g7420.ct000919/. Accessed May 13, 2016. 


\section{Bibliography}

Allardyce, Gilbert. "Toward World History: American Historians and the Coming of the World History Course." Journal of World History 1, no. 1 (March 1990): 23-76.

Andrews, Stephen D. "Structuring the Past: Thinking about the History Curriculum." Journal of American History 95, no. 4 (March 2009): 1094-1101.

Ansary, Tamim. Destiny Disrupted: A History of the World Through Islamic Eyes. Reprint edition. New York: PublicAffairs, 2010.

Bell, Earl P. Jr. "Alternative Approaches for Curriculum in American History: An Annual Workshop for Teachers in Secondary Schools." AHA Newsletter 19, no. 2 (February 1981): 8 .

Bentley, Jerry H. "Why Study World History." World History Connected 5, no. 1 (October 2007). http://worldhistoryconnected.press.illinois.edu/5.1/bentley.html. Accessed March 1 st, 2016

Bigelow, Bill. “Whose ‘Terrorism'?” Zinn Education Project, November 8, 2009. http:// zinnedproject.org/materials/whose-terrorism/. Accessed March 1st, 2016

Birnbaum, Michael. "Historians Speak out against Proposed Texas Textbook Changes." The 
Washington Post, March 18, 2010, sec. Education. http://www.washingtonpost.com/wpdyn/content/article/2010/03/17/AR2010031700560.html. Accessed March 3rd, 2016

Chahine, Youssef, Amos Gitai, Alejandro González Iñárritu, Shôhei Imamura, Claude Lelouch, Ken Loach, Samira Makhmalbaf, et al. September 11. Drama, 2002.

Fallace, Thomas D. "The Effects of Life Adjustment Education on the U.S History Curriculum, 1948-1957." History Teacher 44, no. 4 (August 2011): 569-89.

Franklin, Barry M. "Review Essay: The State of Curriculum History." History of Education 28, no. 4 (December 1999): 459-76. doi:10.1080/004676099284573.

Fraser, T. G. The Arab-Israeli Conflict, Third Edition. 3rd edition. Basingstoke, Hampshire England; New York: Palgrave Macmillan, 2007.

Garrett, Alan W. "What Is Curriculum History and Why Is It Important?.," November 1994. http://eric.ed.gov/?id=ED383584. Accessed November 10th. 2015.

Hanlon, James, Gédéon Naudet, and Jules Naudet. 9/11. Documentary, 2002.

Hansen, Jane. "Multiple Literacies in the Content Classroom: High School Students' Connections to U.S. History." Journal of Adolescent \& Adult Literacy 52, no. 7 (April 2009): 597-606. 
Harman, Chris. A People's History of the World: From the Stone Age to the New Millennium. London; New York: Verso, 2008.

Hart, Diane, Bert Bower, and Teachers' Curriculum Institute. History Alive!: Pursuing American Ideals. Palo Alto, CA: Teachers' Curriculum Institute, 2008.

Hartman, Andrew. '“A Trojan Horse for Social Engineering': The Curriculum Wars in Recent American History." Journal of Policy History 25, no. 1 (January 2013): 114-36. doi:10.1017/S0898030612000371.

Kashatus, William C. III. "Forging a Link with 'Our' Past": The Responsibility of Teaching American History." History Teacher 24, no. 1 (November 1990): 113-19.

Kinzer, Stephen. All the Shah's Men: An American Coup and the Roots of Middle East Terror. Hoboken, N.J: Wiley, 2008.

Kliebard, Herbert M. "Why History of Education?" Journal of Educational Research 88, no. 4 (April 3, 1995): 194.

LITTEL, MCDOUGAL. World History: Patterns of Interaction: Student Edition 2007. Student edition. Evanston, III.: MCDOUGAL LITTEL, 2007. 
Loewen, James. Lies My Teacher Told Me: Everything Your American History Textbook Got Wrong. New York NY: Touchstone, 1995.

Miller, Stuart C. "The Interdisciplinary Approach to Teaching Social Studies.” Social Education 28, no. 4 (April 1964): 195-98.

Morowski, Deborah L. "Public Perceptions, Private Agendas." American Educational History Journal 40, no. 1/2 (March 2013): 1-20.

Pincince, John. "Jerry Bentley, World History, and the Decline of the 'West." Journal of World History 25, no. 4 (December 2014): 631-43.

Ragland, Rachel G. “Sustaining Changes in History Teachers' Core Instructional Practices: Impact of Teaching American History Ten Years Later." History Teacher 48, no. 4 (August 2015): 609-40.

Satrapi, Marjane. The Complete Persepolis. New York: Pantheon, 2007.

Sculdella, Vincent. "State Textbook Adoption". Education Commission of the States. http://www.ecs.org/clearinghouse/01/09/23/10923.pdf, 2013. Accessed March 17th, 2016 
Wallace, Mark. "Integrating United States and World History in the High School Curriculum: The Trials and Tribulations of a Good Idea." History Teacher 33, no. 4 (August 2000): 483-94.

Wilson, Anna Victoria, and William E. Segall. "African-American Teachers and Black History in the Curriculum Before Desegregation." Journal of the Midwest History of Education Society 24 (January 1997): 172-74.

Wineburg, Sam, and Chauncey Monte-Sano. 'Famous Americans': The Changing Pantheon of American Heroes." Journal of American History 94, no. 4 (March 2008): $1186-1202$.

Zinn, Howard. A People's History of the United States. Twentieth Anniversary Edition. New York NY: HarperCollins, 2003. 


\section{Appendix 1}

Destiny Disputed: A History of the World Through Islamic Eyes by Tamim Ansary “Whose 'Terrorism?' - A classroom activity enlists students ind defining terrorism and then applying their definitions to world events" by Bill Bigelow historyisaweapon.com - (A website composing primary and secondary source documents dedicated to the voices of minority or marginalized groups and the empowerment and strength that they had)

A People's History of the World: From the Stone Age to the New Millennium by Chris Harmon

A People's History of the United States by Howard Zinn http://www.al-islam.org/lessons-quran-muhsin-qaraati/social-justice - Website which intersects lessons from the Qur'an with modern understandings of social justice and the compatibility of the two.

Choices Curriculum - "Teaching with the News: Oral History and September 11th" http://www.choices.edu/resources/twtn/twtn-911-10-year.php

9/11, directed by Jules Naudet, Gideon Naudet, and James Hanlon

"Whose Wars? Teaching about the Iraq War and the War on Terrorism. A

Rethinking Schools Collection" - Multiple Authors

11/09/01 (International Film composition from eleven different filmmakers from eleven different countries)

Persepolis by Marjane Satrapi

All the Shah's Men: An American Coup and the Roots of Middle East Terror by Stephen Kinzer 
The Arab Israeli Conflict, Third Edition (Studies in Contemporary History) by T.G.

Fraser

Various works by John Esposito, including:

- What Everyone Needs to Know About Islam

- Women In Muslim Family Law

-Who Speaks for Islam? What a Billion Muslims Really Think 